\title{
Review Article \\ Vitamin D Receptor Agonists Target CXCL10: New Therapeutic Tools for Resolution of Inflammation
}

\author{
Sabino Scolletta, ${ }^{1}$ Marta Colletti, ${ }^{2}$ Luigi Di Luigi, ${ }^{2}$ and Clara Crescioli ${ }^{2}$ \\ ${ }^{1}$ Department of Medical Biotechnologies, University of Siena, Viale Bracci 1, 53100 Siena, Italy \\ ${ }^{2}$ Department of Movement, Human and Health Sciences, Unit of Endocrinology, University of Rome Foro Italico, \\ Piazza Lauro de Bosis 15, 00135 Rome, Italy
}

Correspondence should be addressed to Clara Crescioli; clara.crescioli@uniroma4.it

Received 21 December 2012; Accepted 22 March 2013

Academic Editor: Erico Chagas Caperuto

Copyright (C) 2013 Sabino Scolletta et al. This is an open access article distributed under the Creative Commons Attribution License, which permits unrestricted use, distribution, and reproduction in any medium, provided the original work is properly cited.

\begin{abstract}
Understanding the many biological extraskeletal actions of vitamin D has increased in the past decades. Indeed, vitamin D and analogue molecules, besides the classical actions on bone metabolism, exert several beneficial effects on metabolic homeostasis, heart-cardiovascular, brain, and muscle physiological functions, throughout the interaction with the specific vitamin $\mathrm{D}$ receptor (VDR). In particular, VDR agonists powerfully control innate and adaptive immune system with favorable effects on human health. VDR ligands act as immunomodulators that are potent enough to retain anti-inflammatory effects, even though the mechanism underlying those effects is not yet fully elucidated. VDR agonists exert a significant suppression of inflammatory processes switching the immune response from T helper 1 (Th1) to T helper 2 (Th2) dominance and counteracting the self-enhancing inflammatory loop between immune and resident cells, especially by cytokine release impairment. Those molecules are able, indeed, to reduce the release of the interferon (IFN) $\gamma$-induced $10 \mathrm{kDa}$ protein IP-10/CXCL10, a powerful chemokine driving Th1-mediated inflammation. Based on their features, VDR ligands show the potentiality to be included in immunosuppressive regimens, aimed to control autoand alloimmune Th1-driven overreactivity, occurring, for example, in autoimmune disease or graft rejection.
\end{abstract}

\section{Introduction}

The concept that vitamin $\mathrm{D}$, classically categorized as a regulator of calcium/phosphorous balance and bone metabolism, is able to act on the immune system has emerged more than 20 years ago $[1,2]$. Since then, accumulating evidence confirmed that those pharmacologic effects on the immune system are suppressive enough to retain therapeutic potentials for the management of immune-related inflammatory diseases. Furthermore, epidemiological studies show that circulating altered levels of vitamin D are associated with a higher susceptibility to immune-mediated disorders and inflammatory diseases [3].

The pleiotropic activities in immune regulation by VDR agonists rely on their ability to interfere with maturation/differentiation/activation of the majority of the immune system cells which express VDR, such as monocytes, macrophages, B and T lymphocytes, neutrophils, and dendritic cells (DCs). Vitamin D, for example, is able to suppress cellular immune response by inhibiting the proliferation of $\mathrm{T}$ cells and the maturation of DCs, the most potent antigenpresenting cells (APCs) [4]. Hence, vitamin D can polarize Thl immune response, which dominates in inflammation, toward a more regulatory Th2 phenotype, which dominates in tolerogenicity, by specifically repressing Thl cytokine gene transcription in immune cells. Notably, VDR agonists are able to inhibit cytokine expression and release also in tissue resident cells, with a definite anti-inflammatory effect.

In particular, we have previously reported on the ability of two less or nonhypercalcemic VDR ligands, BXL-01-0029 and elocalcitol, to counteract in lymphocytes and different human resident cell types the release of CXCL10 [5-7]; this is a key chemokine triggering Thl inflammatory molecular processes, in auto- or alloimmune response, secreted by several types 
of resident cells (skeletal muscle cells, thyrocytes, cardiomyocytes, tubular renal cells, and human adrenal cells) [7-12].

In the present paper we intend to offer an overview on VDR agonists as new pharmacological tools with antiinflammatory properties on immune and tissue resident cells, with particular attention to CXCL10, as a new biomolecular target for resolution of inflammation.

\section{Vitamin D}

The pleiotropic hormone vitamin $\mathrm{D}$, also known as vitamin $\mathrm{D}_{3}$ or calcitriol, is known since almost 90 years ago to prevent rickets in children, osteomalacia in adults, and hypocalcemic tetany $[13,14]$; for long time, its function has been considered to be exerted exclusively on calcium, phosphorus, and bone metabolism. With the years, beside the other vitamin D functions-for example, on metabolism, cardiovascular system, muscle and brain functions, and cell growth/differentiation-important effects have been documented on the immune system. In fact, more than 25 years ago, the immunomodulatory role of vitamin D emerged [3] after the observation that monocytes/macrophages from patients affected by granulomatous disease sarcoidosis constitutively synthesize the active form of vitamin D [4]. Vitamin D is synthesized through a multistep process, which begins in the skin. The ultraviolet light (appropriate wavelength: 270$300 \mathrm{~nm}$ ) photocatalyzes the conversion of the precursor 7-dehydrocholesterol to previtamin $\mathrm{D}_{3}$ or cholecalciferol, without any significant biological activity until its conversion to the hormonally active form, 1,25-dihydroxycholecalciferol. This conversion occurs in two steps. Within the liver, cholecalciferol is hydroxylated to 25-hydroxycholecalciferol $\left[25(\mathrm{OH}) \mathrm{D}_{3}\right]$ by the enzyme 25-hydroxylase (CYP2R1); within the kidney, 25-hydroxycholecalciferol serves as a substrate for 1-alpha-hydroxylase (CYP27B1), yielding 1,25dihydroxycholecalciferol or calcitriol $\left[1,25(\mathrm{OH})_{2} \mathrm{D}_{3}\right]$, the biologically active form. Each form of vitamin $\mathrm{D}$ is hydrophobic and transported throughout the body by the specific vitamin $\mathrm{D}$ binding proteins (DBP). Vitamin $\mathrm{D}$ action is limited by catabolism - mainly by a 24-hydroxylase (CYP24A1) — which results in 1,24,25-trihydroxyvitamin $\mathrm{D}_{3}\left[1,24,25(\mathrm{OH})_{3} \mathrm{D}_{3}\right]$, a compound with substantially lower affinity for the VDR; this compound is further metabolized to calcitroic acid and secreted in urine. The metabolism of vitamin $\mathrm{D}$ is complex and tightly regulated [15]. Rate limiting steps in the metabolism of vitamin D are the activity of CYP2R1, induced by low $25(\mathrm{OH}) \mathrm{D}_{3}$ levels, and the activity of CYP24A1, induced by high levels of $25(\mathrm{OH}) \mathrm{D}_{3}$, and $1,25(\mathrm{OH}) \mathrm{D}_{3}$ to avoid vitamin $\mathrm{D}$ toxicity. While liver and kidney are the main sites for vitamin D synthesis and degradation, many other tissues (colon, prostate, breast, lung, pancreas, brain, and endothelium) can synthesize and degrade the active form of vitamin D. Vitamin D biologic effects are exerted throughout the interaction with VDR, which is known to be present in over 30 human target tissues, as reported in Table $1[16,17]$.

Such a diffuse expression in several different tissues, together with metabolic enzyme presence, suggests
TABLE 1: VDR is almost ubiquitary expressed in humans. Many of human tissues and organs express VDR: upon ligand-receptor interaction genomic and nongenomic action likely occur by endocrine, paracrine, and autocrine mechanisms.

\begin{tabular}{ll}
\hline \multicolumn{2}{l}{ Human organs and tissues expressing vitamin D receptor (VDR) } \\
\hline Adipose & Pancreatic $\beta$-cell \\
Adrenal & Parathyroid \\
Bone & Parotid \\
Brain & Pituitary \\
Breast & Placenta \\
Cartilage & Prostate \\
Colon & Retina \\
Hair follicle & Skin \\
Heart & Sperm \\
Intestine & Stomach \\
Kidney & Testis \\
Liver & Thymus \\
Lung & Thyroid \\
Immune cells & Tonsils \\
Muscle, smooth and skeletal & Uterus \\
Ovary & \\
\hline
\end{tabular}

paracrine/autocrine mechanisms of actions, in addition to the classical endocrine effect of the hormone.

The dominant genomic pathway, by which vitamin D mediates its biologic effects, involves the regulation of target genes by ligand-receptor complex in the nucleus of target cells [18]. Summarizing, upon ligand-nuclear VDR interaction, vitamin $\mathrm{D}$ forms heterodimers with the retinoid $\mathrm{X}$ receptor (RXR) and its ligand (9 cis-retinoic acid); these dimers subsequently occupy specific binding sites on DNA, the vitamin D response elements (VDREs). In conjunction with other transcription factors, this complex induces the transcription of vitamin $\mathrm{D}$ responsive genes $[19,20]$. Besides the well-characterized nuclear VDR, a less clearly defined cell membrane receptor, which mediates rapid nongenomic actions, has been hypothesized [21, 22]. Rapid nongenomic actions of vitamin $\mathrm{D}$ do not affect the nuclear transcriptional activity. Even if those vitamin D rapid mechanisms are still unclear, evidence suggests that the initiation of the fast nongenomic signal may involve the engagement of either a novel membrane receptor [23] or the nuclear VDR translocation to the cell surface [24].

Vitamin D classical genomic and "new" nongenomic actions are involved in the regulation of several critical functions, such as immunity, angiogenesis, differentiation, apoptosis, and cell growth. The inhibition, for example, by VDR ligands of prostate cell growth, either growth factor induced or neoplastic, is exerted throughout a rapid mechanism that blocks the phosphorylation/activation of growth factor receptors $[25,26]$. In particular, due to their antiproliferative and prodifferentiation properties, known since quite ago [27], VDR ligands control tumoral cell growth in different models of cancer, such as prostate, breast, and colon [2830]. Moreover, a strong epidemiological association between 
prostate, breast, colon cancer, and vitamin $\mathrm{D}$ deficiency has been documented [31].

Interestingly, vitamin $\mathrm{D}$ plays a pivotal role also in immune system cell control and differentiation, with important effects on the immune-mediated response.

\section{Protolerogenic Effects of VDR Agonists}

3.1. Immune System Cells. VDR ligands usually exert their antiproliferative, prodifferentiation, and immunomodulatory effects throughout the activation of VDR-either constitutively present or induced-in the majority of the immune cells $[32,33]$. Figure 1 summarizes the effects of vitamin D in different immune cell types. One of the first evidence for the immunoregulatory role of vitamin $\mathrm{D}$ was proven by the vitamin $\mathrm{D}$-induced differentiation of monocyte precursors into mature macrophages [34]; the VDR high expression in monocytes has been hypothesized to be responsible for an autocrine mechanism for cell maturation, which, in fact, is impaired by vitamin D deficiency [35]. Monocytes from blood mononuclear cells (PBMCs) are able to synthesize vitamin $\mathrm{D}$ under inflammatory stimuli, such as interferon (IFN) $\gamma$ or bacterial antigens [36, 37]; macrophage inflammatory response is modulated by vitamin $\mathrm{D}$ throughout the regulation of the release of critical inflammatory mediators, such as cytokines and chemotactic cytokines or chemokines. In both monocytes and macrophages, vitamin $\mathrm{D}$ regulates its own effects by controlling VDR and CYP27B1 expression and activity; signaling throughout Toll-like receptors (TLRs) is also engaged in association with VDR expression increase. In human monocytes treated with vitamin $\mathrm{D}$, the expression of TLR2, TLR4, and TLR9 is inhibited, and TLR9dependent interleukin (IL)-6 secretion is altered [38]. The observation that vitamin $\mathrm{D}$, while promoting antimicrobial activity in myeloid cells, also inhibits TLR2 and TLR4 expressions in monocytes, suggested a feedback mechanism to prevent inflammatory overresponses by TLR activation at later stage of infection [39]; this downregulatory effect in APC might be one of the key mechanisms by which vitamin $\mathrm{D}$ is able to attenuate excessive Th1-driven inflammation and avoid downstream potential autoimmunity consequence [40]. Some stimulatory effects have been also shown on innate immunity, such as the increase of monocyte proliferation in vitro or IL-1 and cathelicidin (a bactericidal peptide) release by monocytes and macrophages [41, 42]; however, vitamin $\mathrm{D}$ effects on the adaptive immune response are predominantly suppressive.

In $\mathrm{T}$ cells, vitamin $\mathrm{D}$ inhibits not only proliferation but also IL-2 and IFN $\gamma$ gene and protein expressions [43-46], likely through VDR-RXR complex interaction with VDREs in the promoter of the genes [47, 48]; it inhibits IL-17 and IL-2 expressions in $\mathrm{CD}^{+} \mathrm{T}$ cells and decreases $\mathrm{CD} 8^{+} \mathrm{T}$ cellmediated cytotoxicity [49], with an overall effect towards a block of Th1-mediated response. Th2-type tolerogenic response is also promoted by a direct enhancement of IL4 production [4]. Although vitamin D is known to stimulate the development and differentiation of regulatory $\mathrm{T}$ cells (Treg) enhancing their suppressive function [50-52], the direct effect on $\mathrm{T}$ cell differentiation and function is still unknown, since naïve $T$ cells-differently from effector/memory $\mathrm{T}$ cells-express VDR at very low level [42]. However, it is quite clear that Treg cell differentiation is a key event connecting vitamin $\mathrm{D}$ with adaptive immunity, with potential beneficial effects for autoimmune diseases and host-graft rejection $[3,42,53,54]$. It is widely accepted that those immunosuppressive functions are substantially driven by vitamin D induction of tolerogenic DCs [5456]. In DCs, vitamin D inhibits differentiation and function as well, throughout a decrease in the expression of major histocompatibility complex (MHC) class II molecules and CD40, CD80, and CD86 [4, 57-59] costimulatory proteins; it decreases IL-6, IL-23, and IL-12 [60] while simultaneously increases IL-10 production. Those events also mirror a net decrease in Th1 cell response in favor of Th2-mediated events. By reducing IL-6 and IL-23 production, vitamin D likely inhibits also Th17 cells, another T cell subset deeply engaged in inflammatory responses; although the precise mechanism of vitamin D on Th17 regulation is still unclear [3], it seems that vitamin D-mediated Th1 and Th17 suppression occurs throughout Forkhead box protein $3\left(\right.$ Foxp $\left.^{+}\right)$Treg cells expansion [3]. Furthermore, B cell proliferation, plasma-cell differentiation, and immunoglobulin ( $\operatorname{IgG}$ ) secretion are also affected by VDR ligands $[1,61]$, maybe throughout their effect on APC or T cells [62]. Vitamin D is likely to play a pivotal role in the maintenance of $\mathrm{B}$ cell homeostasis by regulating autoantibody production; notably, the correction of vitamin $\mathrm{D}$ deficiency might ameliorate $\mathrm{B}$ cell-mediated autoimmune disorders [63]. Finally, it is likely that endogenous production of vitamin D by macrophage, DCs, and T cells physiologically regulates both innate and adaptive immune responses [6467]. Immune cells, indeed, seem to be not simple targets of VDR agonists but responsible for activation/inactivation of vitamin D metabolites [68].

3.2. Organ/Tissue Resident Cells. The ability of VDR agonists to modify the function of $\mathrm{T}$ cells and DCs depends not only on VDR expression in both cell types, but also on the presence of common targets in their signal transduction pathways, such as the nuclear factor $\kappa \mathrm{B}$ (NF- $\kappa \mathrm{B})$ [69]. NF$\kappa \mathrm{B}$ is a transcription factor well known to play a pivotal role in proinflammatory cytokine and chemokine production and release not just by immune system cells [70] but, remarkably, by different tissue resident cells, as previously reported [7$10,12]$. Based on VDR agonist capacity to inhibit NF- $\kappa$ B activation in tissue resident cells, a strong reduction in local release of potent chemotactic factors by organ/tissue cells occurs; this, in turn, mirrors a reduced recruitment of Th1 cells, macrophages, and DCs to the site of inflammation. That feature of VDR agonists is particularly relevant for the treatment of inflammation involved in both auto- or alloimmune response, since it counteracts the mechanisms underlying the self-enhancing inflammatory loop between immune and resident cells. The potential therapeutic application of the less-hypercalcemic VDR agonist BXL-219 for autoimmune type 1 diabetes (T1D) has been highlighted in nonobese diabetic (NOD) mice, which retain a pathogenesis 


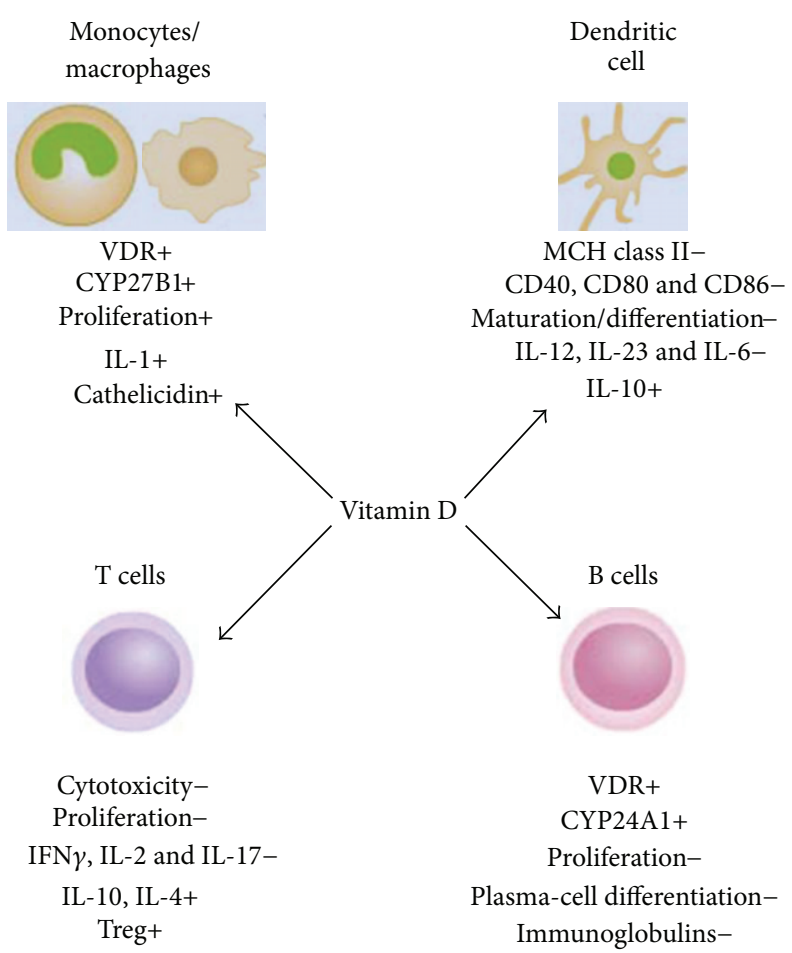

FIGURE 1: Effects of vitamin D on different immune system cells. Vitamin D regulates several immune system cell functions. It stimulates monocyte proliferation and differentiation towards macrophage-like cells, by self-increasing VDR, CYP27B, and IL-1 expressions; this "fastforward" autocrine mechanism seems to be the basis for the subsequent maturation into macrophages, which does not take place in vitamin $\mathrm{D}$ deficient conditions; macrophage specific surface antigen expression is also enhanced. Vitamin D prevents T cells from proliferation, maturation, and releasing Thl-type molecules, such as IFN $\gamma$, IL-2, and IL-17, whereas it promotes Treg development. Vitamin D treatment prevents DCs from maturation and differentiation as well, by MHC class II, costimulatory factors, and interleukin downregulation. Vitamin $\mathrm{D}$-induced protolerogenic DCs seem to be the key event for suppressive effects on immune system cells. Downregulation of B cell proliferation and maturation seems to be an indirect consequence of the suppressive effect exerted by vitamin D on T cells and APC. $(+)$ and $(-)$ indicate induction or inhibition.

similar to the human disease. In this model, BXL-219-induced block of NF- $\kappa$ Bp 65 nuclear translocation is associated with decreased CXCL10 production by pancreatic islets, even in presence of restimulation with TLR agonists; this is reflected in a significant decrease in Th1 cell organ infiltration [71]. Similarly, we have reported that elocalcitol or BXL-628, a nonhypercalcemic VDR agonist, impairs NF- $\kappa$ Bp 65 and STAT1 nuclear translocation directly in human thyrocytes in association with a significant decrease in cytokine-induced CXCL10 release. This effect, in addition to a decreased Th1- and Th17-cytokine secretion by $\mathrm{CD}^{+}{ }^{+} \mathrm{T}$ cells, makes elocalcitol to be a potential pharmacological tool in the treatment of autoimmune thyroid diseases [5].

\section{CXCL10}

Chemokines and their receptors are so far critical during inflammation to become novel targets for immunointervention $[72,73]$.

Among chemokines, CXCL10 plays a critical role in the initiation and maintenance of Th1-polarized response in autoimmune diseases or in graft injury; it appears to be directly linked to the disease pathogenesis and not related to a generic inflammatory status [11]. CXCL10 belongs to CXC chemokine subfamily and modulates innate and adaptive immune responses by controlling leukocyte trafficking [11, 74]. Under proinflammatory conditions, CXCL10 is secreted by several types of immune cells and by different resident cell types, as well [11]. CXCL10 exerts its action by binding the receptor CXCR3. Remarkably, local tissue secretion of CXCL10 represents the driving force for the recruitment of cytotoxic immune CXCR3-positive cells, such as T, natural killer (NK), B cells, macrophages, and DCs [75-77]. In particular, subtype A receptor activation leads to a potent CXCL10-induced chemotaxis for Th1 cell recruitment into inflammation sites [78], while the activation of subtype $B$, selectively expressed in human microvascular endothelial cells, is essentially involved in angiogenesis inhibition [79].

Hence, local CXCL10 production in inflammation sites is responsible for a positive feedback loop between IFN $\gamma$ producing Th1 cells and resident cells that, in turn, release CXCL10 upon IFN $\gamma$ stimulation, as summarized in Figure 2 [80]. By those mechanisms a dominance of Thl-type cytokines and inflammatory response occurs together with a simultaneous Th2-type response downregulation.

The induction of CXCL10, important to protect against bacteria and some viruses infections, is described to be associated with inflammation processes engaged either in 


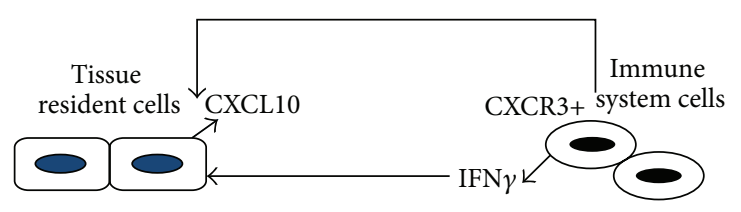

FIgURE 2: CXCL10-CXCR3 axis. CXCL10 secreted by different types of organ-resident cells under IFN $\gamma$ induction is a potent chemoattractant for CXCR3-positive immune cells, in particular for activated T cells. T cell recruitment to sites of inflammation leads to an enhanced local increase of IFN $\gamma$, which, in turn, stimulates CXCL10 secretion by tissue cells; thus, a self-promoting inflammatory loop is established between resident and immune cells, making CXCL10-CXCR3 axis a therapeutic target for resolution of inflammation.

allo- or autoimmune response. Concerning the latter ones, different autoimmune diseases, such as rheumatoid arthritis (RA), systemic lupus erythematosus (SLE), systemic sclerosis (SSc), multiple sclerosis (MS), autoimmune thyroid diseases, Addison's disease, and T1D, are associated with an enhanced tissue expression of CXCL10, not only with increased circulating levels [81-85].

CXCL10-CXCR3 axis plays a pivotal role in the pathogenesis of graft failure and organ rejection, as well. In fact, CXCL10 is critical in promoting and amplifying host alloresponses responsible for acute allograft rejection [86-91]: CXCL10- or CXCR3-gene-deficient mice show permanent engraftment of cardiac transplants $[86,92]$. In cardiac and small bowel models of allograft rejection, CXCL10 neutralization with monoclonal antibodies prolongs the allograft survival [86, 87]. CXCL10 intragraft expression level is associated with human renal [79], lung [89], and cardiac $[90,91]$ allograft rejections. In addition, intragraft CXCL10 expression correlates with damage degree, rejection, and even loss of the organ [11].

Circulating levels of CXCL10 are also increased and associated with the rejection rate in human recipients undergoing transplantation of organs (such as kidney, heart, lung, and liver), cardiopulmonary bypass, and allogeneic stem cell transplantation (SCT) [11, 93]. Importantly, CXCL10 high pretransplant serum levels may predict the risk for the development of acute rejection and chronic allograft vasculopathy (CAV) in different human organ rejection settings [11]. In particular, pretransplant CXCL10 serum assessment may be helpful in the prospective determination of the use of immune suppression therapy, in both renal and heart transplantations [11].

\section{VDR Agonists and CXCL10}

The protolerogenic properties of VDR agonists, as discussed above, render them suitable candidates as immunosuppressants for either autoimmune diseases or graft rejection, as clearly summarized by Mathieu and Adorini, since quite ago [94]. The in vivo effect of some VDR agonists on inflammatory mediators/processes involved in different diseases is depicted in Table 2 [95-102].

VDR agonists, besides their ability to switch the immune system cell balance from Th1 to Th2 dominance, are able to counteract CXCL10 production and release by several resident cell types [5-7]. Indeed, as previously mentioned, VDR ligands can prevent CXCL10 release by human thyrocytes or murine pancreatic cells, with potential benefits in autoimmune diabetes or thyroiditis $[5,53]$. Those data are particularly intriguing in the light of the results from epidemiologic studies which underline an inverse correlation observed between vitamin D level and some autoimmune diseases, as SLE, RA, MS or SSc, in which chemokines seem to be engaged [103]; in addition, the vitamin $\mathrm{D}$ intake in early life of animal models prone to common autoimmune disorders (RA, MS, and autoimmune prostatitis) successfully prevents disease occurrence $[4,96,104]$; similarly, vitamin D supplementation in early childhood seems to be able to protect against T1D development [105]; accordingly, vitamin D serum levels are often decreased in patients with T1D [106], and subjects with a vitamin D deficiency are predisposed toward developing the disease $[4,107]$.

It is noteworthy that VDR agonist beneficial effects have been shown in different models of experimental organ transplantation as well-heart [98, 108-110], kidney [111, 112], liver [113, 114], pancreatic islets [71, 115-117], skin [99], and small bowel allografts [98] — since they delay acute and chronic allograft rejection. The latter effect, probably the most interesting in terms of potential clinical application, involves also the reduction of vascular intimal thickening-for example, due to vascular smooth muscle and endothelial cells hyperplasia-in association with a lesser extent of immune cell infiltration, after the treatment with VDR agonists [118]. Remarkably, many of the immunoregulatory properties of VDR agonists favorable in acute and chronic allograft rejection likely rely on their capacity to inhibit CXCL10 production by organ target cells, that is, $\beta$ cells in mouse model of pancreatic islet transplantation [54] or human cardiomyocytes and renal tubular cells $[6,7]$ in heart or kidney transplantation. Of interest, in our hands, elocalcitol and BXL-01-0029 significantly decreased CXCL10 secretion, without cytotoxic effects neither in resident nor immune cells, differently from the majority of current immunosuppressants. Indeed, both VDR ligands left unchanged cardiac, renal, and $\mathrm{CD} 4{ }^{+} \mathrm{T}$ cell viability, acting specifically on CXCL10 release $[6,7]$. This effect is in line with the concept that vitamin $\mathrm{D}$ in vivo plays a pivotal role in immune homeostasis maintenance without strict immunosuppressants effects [68].

This observation could be of particular relevance as VDR agonists might serve as dose-reducing agents to add to conventional immunosuppressants in organ rejection management or autoimmune disease. Vitamin D analogues successfully decreased the doses of conventional immunosuppressive drugs in experimental autoimmune encephalomyelitis (EAE) model [4]; furthermore, in EAE, the addition of the vitamin D analogue TX527, with reduced calcemic activity, 
TABLE 2: In vivo effect of some VDR agonists. Vitamin D analogs suppress inflammatory mediators and processes resulting in disease prevention.

\begin{tabular}{|c|c|c|c|}
\hline Disease & Analogs & Main in vivo effects & Reference \\
\hline Type 1 diabetes & KH1060 & $\begin{array}{l}\text { Type I diabetes prevention without significant effects on } \\
\text { calcium or bone metabolism }\end{array}$ & {$[95]$} \\
\hline Autoimmune prostatitis & BXL-628 & Inhibition of the intraprostatic inflammatory response & {$[96]$} \\
\hline Interstitial cystitis & BXL-628 & Reduction of mast cell degranulation & {$[97]$} \\
\hline Heart and small bowel graft & MC-1288 & Delay/prevention of graft rejection & {$[98]$} \\
\hline Skin allograft & KH1060, СB966 & Skin allograft survival prolongation & [99] \\
\hline Collagen-induced arthritis (CIA) & MC-1288 & CIA prevention and suppression & {$[100]$} \\
\hline Inflammatory bowel disease & TX527 & $\begin{array}{l}\text { Reduction in mucosal damage and crypt loss and } \\
\text { suppression of the infiltration of immune cells }\end{array}$ & {$[101]$} \\
\hline $\begin{array}{l}\text { Experimental autoimmune } \\
\text { encephalomyelitis (EAE) }\end{array}$ & TX527 & EAE prevention & {$[102]$} \\
\hline
\end{tabular}

empowered the protective effect of IFN- $\beta$ and CsA regimens, suggesting that this compound could be considered for clinical intervention in MS [102]; it is of interest that an association between CXCL10 and subjects affected with MS has been previously shown [119].

In organ transplantation, additive or synergistic effects are reported with VDR ligands and cyclosporine A (CsA), tacrolimus (FK-506) and sirolimus [120]. The combination of low-dose CsA with VDR agonists results in a significant decrease of IL-2 and IL-12 expressions and increased IL10 in kidney allografts [112], likely by a reduction of renal bioactive transforming growth factor (TGF)- $\beta$. Furthermore, paricalcitol, a VDR activator, combined with trandolapril, an angiotensin-converting enzyme inhibitor, ameliorates obstructive nephropathy in a mouse model [121]. In humans, a retrospective study reports that vitamin $\mathrm{D}$ administration is able to delay renal graft loss in patients receiving conventional immunosuppressive drugs [122]. In isolated human tubular renal cells, the addition of BXL-01-0029 allows to lower FK506 doses to reach the same inhibitory effect on cytokineinduced CXCL10 secretion [7].

\section{Remarks and Conclusions}

Given the pleiotropic effects of VDR agonists, based on their multifaceted interaction with immune and resident cells, it seems mandatory to encourage the research on those molecules, which, in light of their properties-due to their features to balance immune system homeostasis without being classical "immunosuppressants" - appear optimal candidates as novel therapeutic agents for Th1-driven inflammatory disease resolution. Large placebo-controlled, randomized-controlled trials should be encouraged since some discrepancies have been reported between in vivo and in vitro effects of vitamin $\mathrm{D}$ and its analogues, depending on both chemical structure (side chain configuration) and target cells [123]. Many clinical trials have been or are currently conducted by several investigators to test the therapeutic application of vitamin $\mathrm{D}$ or its derivatives in inflammatory processes underlying different pathologic conditions and diseases, that is, metabolic and/or kidney diseases (ClinicalTrial.gov,
NCT01752244 and NCT00656032), inflammatory bowel diseases (Crohn's disease or ulcerative colitis, ClinicalTrial.gov NCT00122184 and NCT01426724), musculoskeletal diseases (ClinicalTrial.gov NCT01417923 and NCT01400009), and cardiovascular diseases (ClinicalTrial.gov NCT01331317). In this scenario, it is of particular interest a clinical trial evaluating vitamin D repletion, inflammation, and CXCL10 (ClinicalTrial.gov NCT01570309) in coronary artery disease.

Notably, VDR ligands are able to block CXCL10, that is a potential biomarker to monitor the inflammatory status but, more importantly for the topic of this paper, it represents a novel therapeutic target by which; that is, it could be feasible to fine-tune therapy for patients undergoing organ transplantation [11].

Furthermore, another benefit associated with the addition of VDR ligands to standard immunosuppressive regimens is related to their protective effects on bone loss [124]. Indeed, immunosuppressive agents are often associated with detrimental effects on bone. Together with bisphosphonates, vitamin $\mathrm{D}$ metabolites are the more extensively used molecules for bone-loss treatment. At variance with the first ones [118, 125], vitamin D analogues are indicated also in patients with adynamic bone disease.

Finally, it is known since long time ago that vitamin $\mathrm{D}$ does not significantly interfere with protective immune response against infective pathogens [126] and displays antineoplastic properties [127], both quite relevant benefits in order to avoid opportunistic infection or tumor development, often associated with immunosuppression.

Despite the many advantages so far summarized, the use of VDR agonists in clinics is until now limited to calcipotriol, a vitamin $\mathrm{D}$ analogue topically applied for the treatment of psoriasis [128].

The limit in therapeutic applications of vitamin D undoubtedly relies on the systemic toxicity associated with long-term intake of this hormone; in fact, the supraphysiological doses of vitamin $\mathrm{D}$ necessary to reach the low local effective concentration (about $10^{-10} \mathrm{M}$ ) are associated with the undesirable risk of hypercalcemia [3, 129]. Therefore, the introduction of new molecules with immunosuppressive features without causing significant hypercalcemia has 
been strongly encouraged since a while [130]. Actually, drug development efforts should keep on designing vitamin $\mathrm{D}$ analogues retaining further distinct separation between immunomodulatory and hypercalcemic potency. Thus, the use of molecules as BXL-01-0029 or elocalcitol, with less or none hypercalcemic activity-and, therefore, without systemic toxicity - seems suitable for inclusion in immunosuppressive regimens, since they own the potentiality to lower the doses of current immunosuppressants and, thus, to reduce the side-effects associated with immunosuppression.

\section{Conflict of Interests}

The authors declare that there is no conflict of interests.

\section{References}

[1] J. M. Lemire, J. S. Adams, R. Sakai, and S. C. Jordan, "1 $\alpha, 25$-Dihydroxyvitamin $\mathrm{D}_{3}$ suppresses proliferation and immunoglobulin production by normal human peripheral blood mononuclear cells," Journal of Clinical Investigation, vol. 74, no. 2, pp. 657-661, 1984.

[2] W. F. C. Rigby, T. Stacy, and M. W. Fanger, "Inhibition of T lymphocyte mitogenesis by 1,25-dihydroxyvitamin $\mathrm{D}_{3}$ (calcitriol)," Journal of Clinical Investigation, vol. 74, no. 4, pp. 1451-1455, 1984.

[3] M. Di Rosa, M. Malaguarnera, F. Nicoletti, and L. Malaguernera, "Vitamin $\mathrm{D}_{3}$ : a helpful immuno-modulator," Immunology, vol. 134, pp. 123-139, 2011.

[4] E. Van Etten and C. Mathieu, "Immunoregulation by 1,25dihydroxyvitamin $\mathrm{D}_{3}$ : basic concepts," Journal of Steroid Biochemistry and Molecular Biology, vol. 97, no. 1-2, pp. 93-101, 2005.

[5] E. Borgogni, E. Sarchielli, M. Sottili et al., "Elocalcitol inhibits inflammatory responses in human thyroid cells and T cells," Endocrinology, vol. 149, no. 7, pp. 3626-3634, 2008.

[6] M. Sottili, L. Cosmi, E. Borgogni et al., "Immunomodulatory effects of BXL-01-0029, a less hypercalcemic vitamin D analogue, in human cardiomyocytes and T cells," Experimental Cell Research, vol. 315, no. 2, pp. 264-273, 2009.

[7] C. Sagrinati, M. Sottili, B. Mazzinghi et al., "Comparison between VDR analogs and current immunosuppressive drugs in relation to CXCL10 secretion by human renal tubular cells," Transplant International, vol. 23, no. 9, pp. 914-923, 2010.

[8] C. Crescioli, M. Sottili, P. Bonini et al., "Inflammatory response in human skeletal muscle cells: CXCL10 as potential therapeutic target," European Journal of Cell Biology, vol. 91, pp. 139-149, 2012.

[9] C. Crescioli, L. Cosmi, E. Borgogni et al., "Methimazole inhibits CXC chemokine ligand 10 secretion in human thyrocytes," Journal of Endocrinology, vol. 195, no. 1, pp. 145-155, 2007.

[10] C. Crescioli, R. Squecco, L. Cosmi et al., "Immunosuppression in cardiac graft rejection: a human in vitro model to study the potential use of new immunomodulatory drugs," Experimental Cell Research, vol. 314, no. 6, pp. 1337-1350, 2008.

[11] P. Romagnani and C. Crescioli, "CXCL10: a candidate biomarker in transplantation," Clinica Chimica Acta, vol. 413, pp. 1364-1373, 2012.

[12] M. Rotondi, A. Falorni, A. De Bellis et al., "Elevated serum interferon- $\gamma$-inducible chemokine-10/CXC chemokine ligand10 in autoimmune primary adrenal insufficiency and in vitro expression in human adrenal cells primary cultures after stimulation with proinflammatory cytokines," Journal of Clinical Endocrinology and Metabolism, vol. 90, no. 4, pp. 2357-2363, 2005.

[13] H. F. de Luca and M. T. Cadorna, "Vitamin D: its role and uses in immunology," The FASEB Journal, vol. 15, pp. 2579-2584, 2001.

[14] A. W. Norman, Vitamin D: The Calcium Homeostatic Steroid Hormone, Academic Press, New York, NY, USA, 1979.

[15] A. W. Norman and R. Bouillon, "Vitamin D nutritional policy needs a vision for the future," Experimental Biology and Medicine, vol. 235, no. 9, pp. 1034-1045, 2010.

[16] H. Reichel, H. P. Koeffler, and A. W. Norman, "The role of the vitamin D endocrine system in health and disease," The New England Journal of Medicine, vol. 320, pp. 980-991, 1989.

[17] R. Bouillon, W. H. Okamura, and A. W. Norman, "Structurefunction relationships in the vitamin D endocrine system," Endocrine Reviews, vol. 16, no. 2, pp. 200-256, 1995.

[18] J. W. Pike and M. B. Meyer, "The vitamin D receptor: new paradigms for the regulation of gene expression by 1,25dihydroxyvitamin $\mathrm{D}_{3}$," Endocrinology and Metabolism Clinics of North America, vol. 39, no. 2, pp. 255-269, 2010.

[19] R. M. Evans, "The steroid and thyroid hormone receptor superfamily," Science, vol. 240, no. 4854, pp. 889-895, 1988.

[20] C. Carlberg, T. W. Dunlop, C. Frank, and S. Vaisanen, Vitamin $D$, vol. 1, Elsevier, San Diego, Calif, USA, 2005.

[21] A. W. Norman, "Receptors for $1 \alpha, 25 \mathrm{OH}_{2} \mathrm{D}_{3}$ : past, present, and future," Journal of Bone and Mineral Research, vol. 13, no. 9, pp. 1360-1369, 1998.

[22] I. Nemere, "24,25-dihydroxyvitamin $\mathrm{D}_{3}$ suppresses the rapid actions of 1,25- dihydroxyvitamin $\mathrm{D}_{3}$ and parathyroid hormone on calcium transport in chick intestine," Journal of Bone and Mineral Research, vol. 14, no. 9, pp. 1543-1549, 1999.

[23] I. Nemere, M. C. Dormanen, M. W. Hammond, W. H. Okamura, and A. W. Norman, "Identification of a specific binding protein for $1 \alpha, 25$-dihydroxyvitamin $\mathrm{D}_{3}$ in basal-lateral membranes of chick intestinal epithelium and relationship to transcaltachia," Journal of Biological Chemistry, vol. 269, no. 38, pp. 2375023756, 1994.

[24] I. Nemere and D. Larsson, " $1,25 \mathrm{OH}_{2}$-vitamin $\mathrm{D}_{3}$ induces translocation of the vitamin $\mathrm{D}$ receptor (VDR) to the plasma membrane in skeletal muscle cells," Journal of Cellular Biochemistry, vol. 86, no. 1, pp. 128-135, 2002.

[25] C. Crescioli, M. Maggi, G. B. Vannelli et al., "Effect of a vitamin $\mathrm{D}_{3}$ analogue on keratinocyte growth factor-induced cell proliferation in benign prostate hyperplasia," Journal of Clinical Endocrinology and Metabolism, vol. 85, no. 7, pp. 25762583, 2000.

[26] C. Crescioli, M. Maggi, M. Luconi et al., "Vitamin $\mathrm{D}_{3}$ analogue inhibits keratinocyte growth factor signaling and induces apoptosis in human prostate cancer cells," Prostate, vol. 50, no. 1, pp. 15-26, 2002.

[27] E. Abe, C. Miyaura, and H. Sakagami, "Differentiation of mouse myeloid leukemia cells induced by $1 \alpha, 25$-dihydroxyvitamin $\mathrm{D}_{3}$," Proceedings of the National Academy of Sciences of the United States of America, vol. 78, no. 8, pp. 4990-4994, 1981.

[28] L. Bonaccorsi, S. Marchiani, P. Ferruzzi et al., "Non-genomic effects of the androgen receptor and Vitamin D agonist are involved in suppressing invasive phenotype of prostate cancer cells," Steroids, vol. 71, no. 4, pp. 304-309, 2006.

[29] T. Shao, P. Klein, and M. L. Grossbard, "Vitamin D and breast cancer," Oncologist, vol. 17, pp. 36-45, 2012. 
[30] F. Pereira, M. J. Larriba, and A. Munoz, "Vitamin D and colon cancer," Endocrine Related Cancer, vol. 19, pp. R51-R71, 2012.

[31] A. Zittermann, "Vitamin D in preventive medicine: are we ignoring the evidence?” British Journal of Nutrition, vol. 89, pp. 552-572, 2003.

[32] D. M. Provvedini, C. D. Tsoukas, L. J. Deftos, and S. C. Manolagas, "1,25-Dihydroxyvitamin $\mathrm{D}_{3}$ receptors in human leukocytes," Science, vol. 221, no. 4616, pp. 1181-1183, 1983.

[33] F. Baeke, H. Korf, L. Overbergh et al., "Human T lymphocytes are direct targets of 1,25-dihydroxyvitamin $\mathrm{D}_{3}$ in the immune system," Journal of Steroid Biochemistry and Molecular Biology, vol. 121, no. 1-2, pp. 221-227, 2010.

[34] E. Abe, C. Miyaura, H. Tanaka et al., "1 alpha,25dihydroxyvitamin $\mathrm{D}_{3}$ promotes fusion of mouse alveolar macrophages both by a direct mechanism and by a spleen cell-mediated indirect mechanism," Proceedings of the National Academy of Sciences of the United States of America, vol. 80, no. 18, pp. 5583-5587, 1983.

[35] Y. Abu-Amer and Z. Bar-Shavit, "Impaired bone marrowderived macrophage differentiation in vitamin D deficiency," Cellular Immunology, vol. 151, no. 2, pp. 356-368, 1993.

[36] H. P. Koeffler, H. Reichel, J. E. Bishop, and A. W. Norman, “ $\gamma$ Interferon stimulates production of 1,25-dihydroxyvitamin $\mathrm{D}_{3}$ by normal human macrophages," Biochemical and Biophysical Research Communications, vol. 127, no. 2, pp. 596-603, 1985.

[37] H. Reichel, H. P. Koeffler, J. E. Bishop, and A. W. Norman, "25-Hydroxyvitamin $\mathrm{D}_{3}$ metabolism by lipopolysaccharidestimulated normal human macrophages," Journal of Clinical Endocrinology and Metabolism, vol. 64, no. 1, pp. 1-9, 1987.

[38] L. J. Dickie, L. D. Church, L. R. Coulthard, R. J. Mathews, P. Emery, and M. F. McDermott, "Vitamin $\mathrm{D}_{3}$ downregulates intracellular Toll-like receptor 9 expression and Tolllike receptor 9-induced IL-6 production in human monocytes," Rheumatology, vol. 49, no. 8, pp. 1466-1471, 2010.

[39] K. Sadeghi, B. Wessner, U. Laggner et al., "Vitamin $\mathrm{D}_{3}$ downregulates monocyte TLR expression and triggers hyporesponsiveness to pathogen-associated molecular patterns," European Journal of Immunology, vol. 36, no. 2, pp. 361-370, 2006.

[40] Z. Urry, E. Xystrakis, D. F. Richards et al., "Ligation of TLR9 induced on human IL-10-secreting Tregs by $1 \alpha, 25-$ dihydroxyvitamin $\mathrm{D}_{3}$ abrogates regulatory function," Journal of Clinical Investigation, vol. 119, no. 2, pp. 387-398, 2009.

[41] M. Ohta, T. Okabe, and K. Ozawa, " $1 \alpha, 25-$ Dihydroxyvitamin $\mathrm{D}_{3}$ (calcitriol) stimulates proliferation of human circulating monocytes in vitro," FEBS Letters, vol. 185, no. 1, pp. 9-13, 1985.

[42] J. R. Mora, M. Iwata, and U. H. Von Andrian, "Vitamin effects on the immune system: vitamins A and D take centre stage," Nature Reviews Immunology, vol. 8, no. 9, pp. 685-698, 2008.

[43] W. F. C. Rigby, T. Stacy, and M. W. Fanger, "Inhibition of T lymphocyte mitogenesis by 1,25-dihydroxyvitamin $\mathrm{D}_{3}$ (calcitriol)," Journal of Clinical Investigation, vol. 74, no. 4, pp. 1451-1455, 1984.

[44] J. M. Lemire, J. S. Adams, V. Kermani-Arab, A. C. Bakke, R. Sakai, and S. C. Jordan, "1,25-dihydroxyvitamin $\mathrm{D}_{3}$ suppresses human T helper/inducer lymphocyte activity in vitro," Journal of Immunology, vol. 134, no. 5, pp. 3032-3035, 1985.

[45] H. Reichel, H. P. Koeffler, A. Tobler, and A. W. Norman, " $1 \alpha, 25$-Dihydroxyvitamin $\mathrm{D}_{3}$ inhibits $\gamma$-interferon synthesis by normal human peripheral blood lymphocytes," Proceedings of the National Academy of Sciences of the United States of America, vol. 84, no. 10, pp. 3385-3389, 1987.
[46] W. F. C. Rigby, B. Yirinec, R. L. Oldershaw, and M. W. Fanger, "Comparison of the effects of 1,25-dihydroxyvitamin $\mathrm{D}_{3}$ on $\mathrm{T}$ lymphocyte subpopulations," European Journal of Immunology, vol. 17 , no. 4, pp. 563-566, 1987.

[47] I. Alroy, T. L. Towers, and L. P. Freedman, "Transcriptional repression of the interleukin-2 gene by vitamin $\mathrm{D}_{3}$ : direct inhibition of NFATp/AP-1 complex formation by a nuclear hormone receptor," Molecular and Cellular Biology, vol. 15, no. 10, pp. 5789-5799, 1995.

[48] M. Cippitelli and A. Santoni, "Vitamin $\mathrm{D}_{3}$ : a transcriptional modulator of the interferon- $\gamma$ gene," European Journal of Immunology, vol. 28, pp. 3017-3030, 1998.

[49] M. A. Meehan, R. H. Kerman, and J. M. Lemire, "1,25Dihydroxyvitamin $\mathrm{D}_{3}$ enhances the generation of nonspecific suppressor cells while inhibiting the induction of cytotoxic cells in a human MLR," Cellular Immunology, vol. 140, no. 2, pp. 400409, 1992.

[50] L. E. Jeffery, F. Burke, M. Mura et al., "1,25-Dihydroxyvitamin $\mathrm{D}_{3}$ and IL-2 combine to inhibit T cell production of inflammatory cytokines and promote development of regulatory $\mathrm{T}$ cells expressing CTLA-4 and FoxP3," Journal of Immunology, vol. 183, no. 9, pp. 5458-5467, 2009.

[51] S. Gorman, L. Alexandra Kuritzky, M. A. Judge et al., "Topically applied 1,25-dihydroxyvitamin $\mathrm{D}_{3}$ enhances the suppressive activity of $\mathrm{CD} 4^{+} \mathrm{CD} 25^{+}$cells in the draining lymph nodes," Journal of Immunology, vol. 179, no. 9, pp. 6273-6283, 2007.

[52] M. Ghoreishi, P. Bach, J. Obst, M. Komba, J. C. Fleet, and J. P. Dutz, "Expansion of antigen-specific regulatory T cells with the topical vitamin D analog calcipotriol," Journal of Immunology, vol. 182, no. 10, pp. 6071-6078, 2009.

[53] S. Gregori, N. Giarratana, S. Smiroldo, M. Uskokovic, and L. Adorini, "A $1 \alpha, 25$-dihydroxyvitamin $\mathrm{D}_{3}$ analog enhances regulatory T-cells and arrests autoimmune diabetes in NOD mice," Diabetes, vol. 51, no. 5, pp. 1367-1374, 2002.

[54] S. Gregori, M. Casorati, S. Amuchastegui, S. Smiroldo, A. M. Davalli, and L. Adorini, "Regulatory T cells induced by $1 \alpha, 25-$ dihydroxyvitamin $\mathrm{D}_{3}$ and mycophenolate mofetil treatment mediate transplantation tolerance," Journal of Immunology, vol. 167, no. 4, pp. 1945-1953, 2001.

[55] G. Penna, A. Roncari, S. Amuchastegui et al., "Expression of the inhibitory receptor ILT3 on dendritic cells is dispensable for induction of $\mathrm{CD}^{+} \mathrm{Foxp}^{+}$regulatory $\mathrm{T}$ cells by 1,25 dihydroxyvitamin $\mathrm{D}_{3}$," Blood, vol. 106, no. 10, pp. 3490-3497, 2005.

[56] X. Dong, L. A. Bachman, R. Kumar, and M. D. Griffin, "Generation of antigen-specific, interleukin-10-producing T-cells using dendritic cell stimulation and steroid hormone conditioning," Transplant Immunology, vol. 11, no. 3-4, pp. 323-333, 2003.

[57] J. Fritsche, K. Mondal, A. Ehrnsperger, R. Andreesen, and M. Kreutz, "Regulation of 25 -hydroxyvitamin $\mathrm{D}_{3}-1 \alpha$-hydroxylase and production of $1 \alpha, 25$-dihydroxyvitamin $\mathrm{D}_{3}$ by human dendritic cells," Blood, vol. 102, no. 9, pp. 3314-3316, 2003.

[58] G. Penna and L. Adorini, " $1 \alpha, 25$-dihydroxyvitamin $\mathrm{D}_{3}$ inhibits differentiation, maturation, activation, and survival of dendritic cells leading to impaired alloreactive T cell activation," Journal of Immunology, vol. 164, no. 5, pp. 2405-2411, 2000.

[59] M. D. Griffin, W. Lutz, V. A. Phan, L. A. Bachman, D. J. McKean, and R. Kumar, "Dendritic cell modulation by $1 \alpha, 25$ dihydroxyvitamin $\mathrm{D}_{3}$ and its analogs: a vitamin $\mathrm{D}$ receptor-dependent pathway that promotes a persistent state of immaturity in vitro and in vivo," Proceedings of the National Academy of Sciences of the United States of America, vol. 98, no. 12, pp. 6800-6805, 2001. 
[60] A. W. Pedersen, K. Holmstrøm, S. S. Jensen et al., "Phenotypic and functional markers for $1 \alpha, 25$-dihydroxyvitamin $\mathrm{D}_{3}$ modified regulatory dendritic cells," Clinical and Experimental Immunology, vol. 157, no. 1, pp. 48-59, 2009.

[61] H. Tokuyama and Y. Tokuyama, "The regulatory effects of alltrans-retinoic acid on isotype switching: retinoic acid induces IgA switch rearrangement in cooperation with IL-5 and inhibits IgG1 switching," Cellular Immunology, vol. 192, no. 1, pp. 41-47, 1999.

[62] K. Muller, C. Heilmann, L. K. Poulsen, T. Barington, and $\mathrm{K}$. Bendtzen, "The role of monocytes and $\mathrm{T}$ cells in 1,25dihydroxyvitamin $\mathrm{D}_{3}$ mediated inhibition of $\mathrm{B}$ cell function in vitro," Immunopharmacology, vol. 21, no. 2, pp. 121-128, 1991.

[63] S. Chen, G. P. Sims, X. C. Xiao, Y. G. Yue, S. Chen, and P. E. Lipsky, "Modulatory effects of 1,25-dihydroxyvitamin $\mathrm{D}_{3}$ on human B cell differentiation," Journal of Immunology, vol. 179, no. 3, pp. 1634-1647, 2007.

[64] P. F. Barnes, R. L. Modlin, D. D. Bikle, and J. S. Adams, "Transpleural gradient of 1,25-dihydroxyvitamin D in tuberculous pleuritis," Journal of Clinical Investigation, vol. 83, no. 5, pp. 1527-1532, 1989.

[65] J. Cadranel, M. Garabedian, B. Milleron, H. Guillozo, G. Akoun, and A. J. Hance, "1,25(OH)2D2 production by $\mathrm{T}$ lymphocytes and alveolar macrophages recovered by lavage from normocalcemic patients with tuberculosis," Journal of Clinical Investigation, vol. 85, no. 5, pp. 1588-1593, 1990.

[66] L. Overbergh, B. Decallonne, D. Valckx et al., "Identification and immune regulation of 25-hydroxyvitamin D-1- $\alpha$ hydroxylase in murine macrophages," Clinical and Experimental Immunology, vol. 120, no. 1, pp. 139-146, 2000.

[67] M. Hewison, L. Freeman, S. V. Hughes et al., "Differential regulation of vitamin $\mathrm{D}$ receptor and its ligand in human monocyte-derived dendritic cells," Journal of Immunology, vol. 170, no. 11, pp. 5382-5390, 2003.

[68] E. Peelen, S. Knippenberg, A. H. Muris et al., "Effects of vitamin $\mathrm{D}$ on the pheripheral adaptive immune system: a review," Autoimmunity Reviews, vol. 10, pp. 733-743, 2011.

[69] L. Adorini, "Intervention in autoimmunity: the potential of vitamin D receptor agonists," Cellular Immunology, vol. 233, no. 2, pp. 115-124, 2005.

[70] Q. Li and I. M. Verma, "NF- $\kappa$ B regulation in the immune system," Nature Reviews Immunology, vol. 2, no. 10, pp. 725-734, 2002.

[71] N. Giarratana, G. Penna, S. Amuchastegui, R. Mariani, K. C. Daniel, and L. Adorini, "A vitamin D analog down-regulates proinflammatory chemokine production by pancreatic islets inhibiting T cell recruitment and type 1 diabetes development," Journal of Immunology, vol. 173, no. 4, pp. 2280-2287, 2004.

[72] M. E. DeVries, K. A. Hosiawa, C. M. Cameron et al., "The role of chemokines and chemokine receptors in alloantigenindependent and alloantigen-dependent transplantation injury," Seminars in Immunology, vol. 15, no. 1, pp. 33-48, 2003.

[73] W. W. Hancock, L. Wang, Q. Ye, R. Han, and I. Lee, "Chemokines and their receptors as markers of allograft rejection and targets for immunosuppression," Current Opinion in Immunology, vol. 15, no. 5, pp. 479-486, 2003.

[74] A. D. Luster and J. V. Ravetch, "Biochemical characterization of a $\gamma$ interferon-inducible cytokine (IP-10)," Journal of Experimental Medicine, vol. 166, no. 4, pp. 1084-1097, 1987.

[75] M. Loetscher, B. Gerber, P. Loetscher et al., "Chemokine receptor specific for IP10 and Mig: structure, function, and expression in activate T-Lymphocytes," Journal of Experimental Medicine, vol. 184, no. 3, pp. 963-969, 1996.

[76] M. Loetscher, P. Moetscher, N. Brass, E. Meese, and B. Moser, "Lymphocyte-specific chemokine receptor CXCR3: regulation, chemokine binding and gene localization," European Journal Immunology, vol. 28, pp. 3696-3705, 1998.

[77] S. Qin, J. B. Rottman, P. Myers et al., “The chemokine receptors CXCR3 and CCR5 mark subsets of T cells associated with certain inflammatory reactions," Journal of Clinical Investigation, vol. 101, no. 4, pp. 746-754, 1998.

[78] M. O. Aksoy, Y. Yang, R. Ji et al., "CXCR3 surface expression in human airway epithelial cells: cell cycle dependence and effect on cell proliferation," American Journal of Physiology, vol. 290, no. 5, pp. L909-L918, 2006.

[79] L. Lasagni, M. Francalanci, F. Annunziato et al., "An alternatively spliced variant of CXCR3 mediates the inhibition of endothelial cell growth induced by IP-10, Mig, and I-TAC, and acts as functional receptor for platelet factor 4," Journal of Experimental Medicine, vol. 197, no. 11, pp. 1537-1549, 2003.

[80] J. D. Campbell, V. Gangur, F. E. Simons, and K. T. HayGlass, "Allergic humans are hyporesponsive to a CXCR3 ligandmediated Thl immunity-promoting loop," The FASEB Journal, vol. 18, no. 2, pp. 329-331, 2004.

[81] R. Hanaoka, T. Kasama, M. Muramatsu et al., "A novel mechanism for the regulation of IFN-gamma inducible protein10 expression in rheumatoid arthritis," Arthritis Research \& Therapy, vol. 5, no. 2, pp. R74-R81, 2003.

[82] S. Narumi, T. Takeuchi, Y. Kobayashi, and K. Konishi, "Serum levels of IFN-inducible protein-10 relating to the activity of systemic lupus erythematosus," Cytokine, vol. 12, no. 10, pp. 1561-1565, 2000.

[83] H. Fujii, Y. Shimada, M. Hasegawa, K. Takehara, and S. Sato, "Serum levels of a Th1 chemoattractant IP-10 and Th2 chemoattractants, TARC and MDC, are elevated in patients with systemic sclerosis," Journal of Dermatological Science, vol. 35, no. 1, pp. 43-51, 2004.

[84] T. L. Sørensen, M. Tani, J. Jensen et al., "Expression of specific chemokines and chemokine receptors in the central nervous system of multiple sclerosis patients," Journal of Clinical Investigation, vol. 103, no. 6, pp. 807-815, 1999.

[85] M. Rotondi, L. Chiovato, S. Romagnani, M. Serio, and P. Romagnani, "Role of chemokines in endocrine autoimmune diseases," Endocrine Reviews, vol. 28, no. 5, pp. 492-520, 2007.

[86] W. W. Hancock, B. Lu, W. Gao et al., "Requirement of the chemokine receptor CXCR3 for acute allograft rejection," Journal of Experimental Medicine, vol. 192, no. 10, pp. 1515-1519, 2000.

[87] Z. Zhang, L. Kaptanoglu, W. Haddad et al., "Donor T cell activation initiates small bowel allograft rejection through an IFN- $\gamma$-inducible protein-10-dependent mechanism," Journal of Immunology, vol. 168, no. 7, pp. 3205-3212, 2002.

[88] S. Segerer, Y. Cui, F. Eitner et al., "Expression of chemokines and chemokine receptors during human renal transplant rejection," American Journal of Kidney Diseases, vol. 37, no. 3, pp. 518-531, 2001.

[89] C. Agostini, F. Calabrese, F. Rea et al., "CXCR3 and its ligand CXCL10 are expressed by inflammatory cells infiltrating lung allografts and mediate chemotaxis of T cells at sites of rejection," American Journal of Pathology, vol. 158, no. 5, pp. 1703-1711, 2001.

[90] M. Melter, A. Exeni, M. E. J. Reinders et al., "Expression of the chemokine receptor cxcr3 and its ligand ip-10 during human 
cardiac allograft rejection," Circulation, vol. 104, no. 21, pp. 2558-2564, 2001.

[91] N. M. Fahmy, M. H. Yamani, R. C. Starling et al., "Chemokine and chemokine receptor gene expression indicates acute rejection of human cardiac transplants," Transplantation, vol. 75, no. 1, pp. 72-78, 2003.

[92] W. W. Hancock, W. Gao, V. Csizmadia, K. L. Faia, N. Shemmeri, and A. D. Luster, "Donor-derived IP-10 initiates development of acute allograft rejection," Journal of Experimental Medicine, vol. 193, no. 8, pp. 975-980, 2001.

[93] S. Scolletta, A. Buonamano, M. Sottili, P. Giomarelli, B. Biagioli, and G. B. Vannelli, "CXCL10 release in cardiopulmonary bypass: an in vivo and in vitro study," Biomedicine and Aging Pathology, vol. 2, no. 4, pp. 187-194, 2012.

[94] C. Mathieu and L. Adorini, "The coming of age of 1,25dihydroxyvitamin $\mathrm{D}_{3}$ analogs as immunomodulatory agents," Trends in Molecular Medicine, vol. 8, no. 4, pp. 174-179, 2002.

[95] C. Mathieu, M. Waer, K. Casteels, J. Laureys, and R. Bouillon, "Prevention of type I diabetes in NOD mice by nonhypercalcemic doses of a new structural analog of 1,25dihydroxyvitamin $\mathrm{D}_{3}$, KH1060," Endocrinology, vol. 136, no. 3, pp. 866-872, 1995.

[96] G. Penna, S. Amuchastegui, C. Cossetti et al., "Treatment of experimental autoimmune prostatitis in nonobese diabetic mice by the vitamin D receptor agonist elocalcitol," Journal of Immunology, vol. 177, no. 12, pp. 8504-8511, 2006.

[97] F. Benigni, E. Baroni, M. Zecevic et al., "Oral treatment with a vitamin $\mathrm{D}_{3}$ analogue (BXL628) has anti-inflammatory effects in rodent model of interstitial cystitis," BJU International, vol. 97, no. 3, pp. 617-624, 2006.

[98] C. Johnsson and G. Tufveson, "MC 1288 - a vitamin D analogue with immunosuppressive effects on heart and small bowel grafts," Transplant International, vol. 7, no. 6, pp. 392-397, 1994.

[99] P. Veyron, R. Pamphile, L. Binderup, and J. L. Touraine, “Two novel vitamin D analogues, KH 1060 and CB 966, prolong skin allograft survival in mice," Transplant Immunology, vol. 1, no. 1, pp. 72-76, 1993.

[100] P. Larsson, L. Mattsson, L. Klareskog, and C. Johnsson, “A vitamin D analogue (MC 1288) has immunomodulatory properties and suppresses collagen-induced arthritis (CIA) without causing hypercalcaemia," Clinical and Experimental Immunology, vol. 114, no. 2, pp. 277-283, 1998.

[101] L. Verlinden, C. Leyssens, I. Beullens et al., "The vitamin D analog TX527 ameliorates disease symptoms in a chemically induced model of inflammatory bowel disease," The Journal of Steroid Biochemistry and Molecular Biology, 2012.

[102] E. van Etten, C. Gysemans, D. D. Branisteanu et al., "Novel insights in the immune function of the vitamin D system: synergism with interferon-beta," Journal of Steroid Biochemistry and Molecular Biology, vol. 103, no. 3-5, pp. 546-551, 2007.

[103] Y. Arnson, H. Amital, N. Agmon-Levin et al., "Serum 25$\mathrm{OH}$ vitamin D concentrations are linked with various clinical aspects in patients with systemic sclerosis: a retrospective cohort study and review of the literature," Autoimmunity Reviews, vol. 10, no. 8, pp. 490-494, 2011.

[104] M. T. Cantorna, C. E. Hayes, and H. F. DeLuca, "1,25Dihydroxycholecalciferol inhibits the progression of arthritis in murine models of human arthritis," Journal of Nutrition, vol. 128, no. 1, pp. 68-72, 1998.

[105] J. S. Skyler, "Primary and secondary prevention of Type 1 diabetes," Diabetic Medicine, vol. 30, pp. 161-169, 2013.
[106] B. Littorin, P. Blom, A. Schölin et al., "Lower levels of plasma 25-hydroxyvitamin D among young adults at diagnosis of autoimmune type 1 diabetes compared with control subjects: results from the nationwide Diabetes Incidence Study in Sweden (DISS)," Diabetologia, vol. 49, no. 12, pp. 2847-2852, 2006.

[107] C. Mathieu, C. Gysemans, A. Giulietti, and R. Bouillon, "Vitamin D and diabetes," Diabetologia, vol. 48, no. 7, pp. 1247-1257, 2005.

[108] J. M. Lemire, D. C. Archer, A. Khulkarni, A. Ince, M. R. Uskokovic, and S. Stepkowski, "Prolongation of the survival of murine cardiac allografts by the vitamin $\mathrm{D}_{3}$ analogue 1,25 dihydroxy- $\Delta$ 16-cholecalciferol," Transplantation, vol. 54 , no. 4 , pp. 762-763, 1992.

[109] D. A. Hullett, M. T. Cantorna, C. Redaelli et al., "Prolongation of allograft survival by 1,25 -dihydroxyvitamin $\mathrm{D}_{3}$," Transplantation, vol. 66, no. 7, pp. 824-828, 1998.

[110] S. Amuchastegui, K. C. Daniel, and L. Adorini, "Inhibition of acute and chronic allograft rejection in mouse models by BXL-628, a nonhypercalcemic vitamin D receptor agonist," Transplantation, vol. 80, no. 1, pp. 81-87, 2005.

[111] E. Kallio, P. Hayry, and S. Pakkala, "MC1288, a vitamin D analogue, reduces short- and long-term renal allograft rejection in the rat," Transplantation Proceedings, vol. 28, no. 6, p. 3113, 1996.

[112] C. A. Redaelli, M. Wagner, D. Günter-Duwe et al., " $1 \alpha, 25$ Dihydroxyvitamin $\mathrm{D}_{3}$ shows strong and additive immunomodulatory effects with cyclosporine A in rat renal allotransplants," Kidney International, vol. 61, no. 1, pp. 288-296, 2002.

[113] C. A. Redaelli, M. Wagner, Y. H. Tien et al., " $1 \alpha, 25-$ dihydroxycholecalciferol reduces rejection and improves survival in rat liver allografts," Hepatology, vol. 34, no. 5, pp. 926934, 2001.

[114] A. B. Zhang, S. S. Zheng, C. K. Jia, and Y. Wang, "Effect of 1,25-dihydroxyvitamin $\mathrm{D}_{3}$ on preventing allograft from acute rejection following rat orthotoic liver transplantation," World Journal of Gastroenterology, vol. 9, no. 5, pp. 1067-1071, 2003.

[115] K. M. Casteels, C. Mathieu, M. Waer et al., "Prevention of type I diabetes in nonobese diabetic mice by late intervention with nonhypercalcemic analogs of 1,25-dihydroxyvitamin $\mathrm{D}_{3}$ in combination with a short induction course of cyclosporin A," Endocrinology, vol. 139, pp. 95-102, 1998.

[116] E. Van Etten, C. Gysemans, A. Verstuyf, R. Bouillon, and C. Mathieu, "Immunomodulatory properties of a $1,25 \mathrm{OH}_{2}$ vitamin $\mathrm{D}_{3}$ analog combined with IFN $\beta$ in an animal model of syngeneic islet transplantation," Transplantation Proceedings, vol. 33, no. 3, p. 2319, 2001.

[117] C. Gysemans, M. Waer, J. Laureys, R. Bouillon, and C. Mathieu, "A combination of KH1060, a vitamin $\mathrm{D}_{3}$ analogue, and cyclosporin prevents early graft failure and prolongs graft survival of xenogeneic islets in nonobese diabetic mice," Transplantation Proceedings, vol. 33, no. 3, p. 2365, 2001.

[118] L. Adorini, S. Amuchastegui, and K. C. Daniel, "Prevention of chronic allograft rejection by Vitamin D receptor agonists," Immunology Letters, vol. 100, no. 1, pp. 34-41, 2005.

[119] B. Mazzanti, A. Aldinucci, T. Biagioli et al., "Differences in mesenchymal stem cell cytokine profiles between MS patients and healthy donors: implication for assessment of disease activity and treatment," Journal of Neuroimmunology, vol. 199, no. 1-2, pp. 142-150, 2008.

[120] E. Van Etten, D. D. Branisteanu, A. Verstuyf, M. Waer, R. Bouillon, and C. Mathieu, "Analogs of 1,25-dihydroxyvitamin 
$\mathrm{D}_{3}$ as dose-reducing agents for classical immunosuppressants," Transplantation, vol. 69, no. 9, pp. 1932-1942, 2000.

[121] X. Tan, W. He, and Y. Liu, "Combination therapy with paricalcitol and trandolapril reduces renal fibrosis in obstructive nephropathy," Kidney International, vol. 76, no. 12, pp. 12481257, 2009.

[122] J. K. O'Herrin, D. A. Hullett, D. M. Heisey, H. W. Sollinger, and B. N. Becker, "A retrospective evaluation of (1,25Dihydroxyvitamin $\mathrm{D}_{3}$ and its potential) effects on renal allograft function," American Journal of Nephrology, vol. 22, no. 5-6, pp. 515-520, 2002.

[123] J. Zhao, B. K. Tan, S. Marcelis, A. Verstuyf, and R. Bouillon, "Enhancement of antiproliferative activity of $1 \alpha, 25-$ dihydroxyvitamin $\mathrm{D}_{3}$ (analogs) by cytochrome P450 enzyme inhibitors is compound- and cell-type specific," Journal of Steroid Biochemistry and Molecular Biology, vol. 57, no. 3-4, pp. 197-202, 1996.

[124] H. U. Stempfle, C. Werner, U. Siebert et al., "The role of tacrolimus (FK506)-based immunosuppression on bone mineral density and bone turnover after cardiac transplantation: a prospective, longitudinal, randomized, double-blind trial with calcitriol," Transplantation, vol. 73, no. 4, pp. 547-552, 2002.

[125] V. M. Brandenburg, R. Westenfeld, and M. Ketteler, "The fate of bone after renal transplantation," Journal of Nephrology, vol. 17, no. 2, pp. 190-204, 2004.

[126] M. T. Cantorna, D. A. Hullett, C. Redaelli et al., "1,25Dihydroxyvitamin $\mathrm{D}_{3}$ prolongs graft survival without compromising host resistance to infection or bone mineral density," Transplantation, vol. 66, no. 7, pp. 828-831, 1998.

[127] G. Picotto, A. C. Liaudat, L. Bohl, and N. T. Talamoni, "Molecular aspects of vitamin D anticancer activity," Cancer Investigation, vol. 30, pp. 604-614, 2012.

[128] L. J. Scott, C. J. Dunn, and K. L. Goa, "Calcipotriol ointment: a review of its use in the management of psoriasis," American Journal of Clinical Dermatology, vol. 2, no. 2, pp. 95-120, 2001.

[129] D. B. Endres, "Investigation of hypercalcemia," Clinical Biochemistry, vol. 45, pp. 954-963, 2012.

[130] T. Takahashi and K. Morikawa, "Vitamin D receptor agonists: opportunities and challenges in drug discovery," Current Topics in Medicinal Chemistry, vol. 6, no. 12, pp. 1303-1316, 2006. 


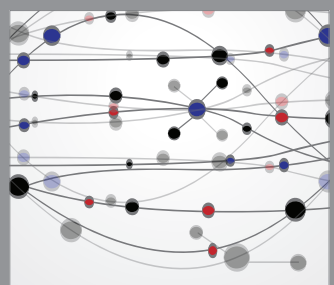

The Scientific World Journal
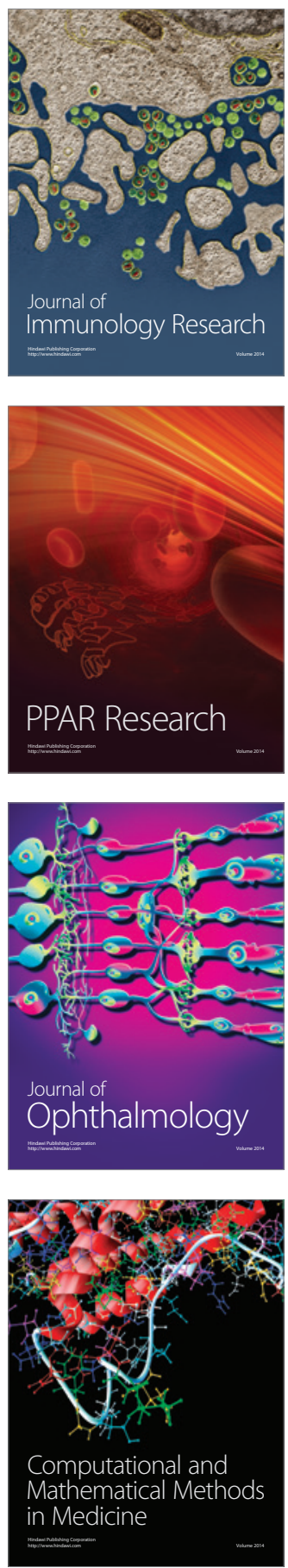

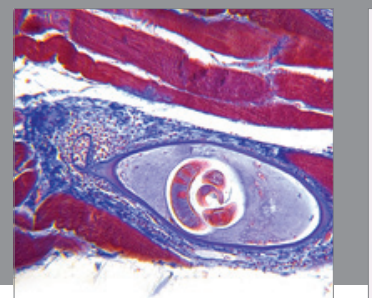

Gastroenterology

Research and Practice
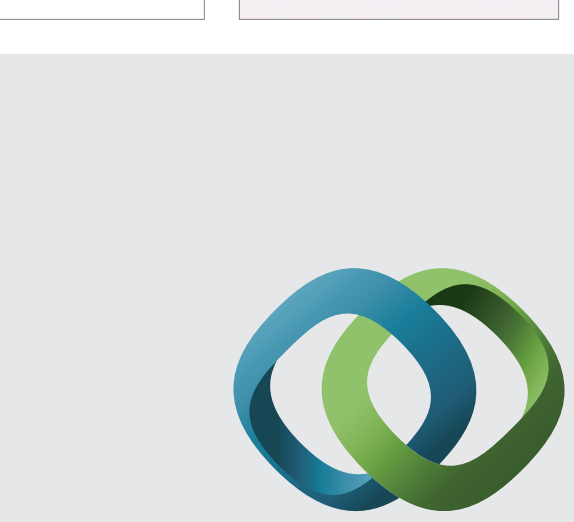

\section{Hindawi}

Submit your manuscripts at

http://www.hindawi.com
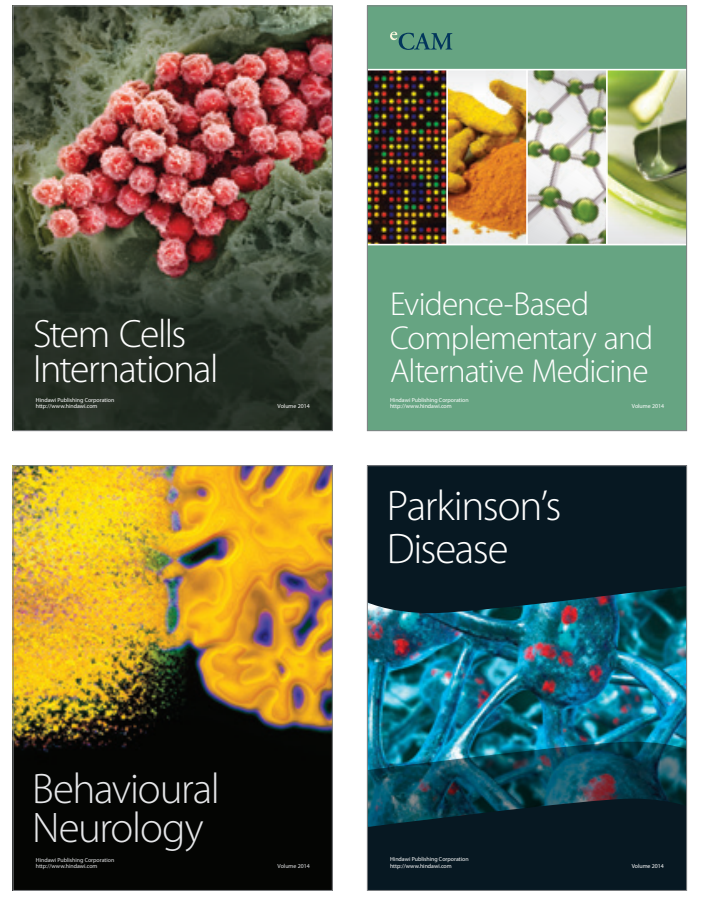
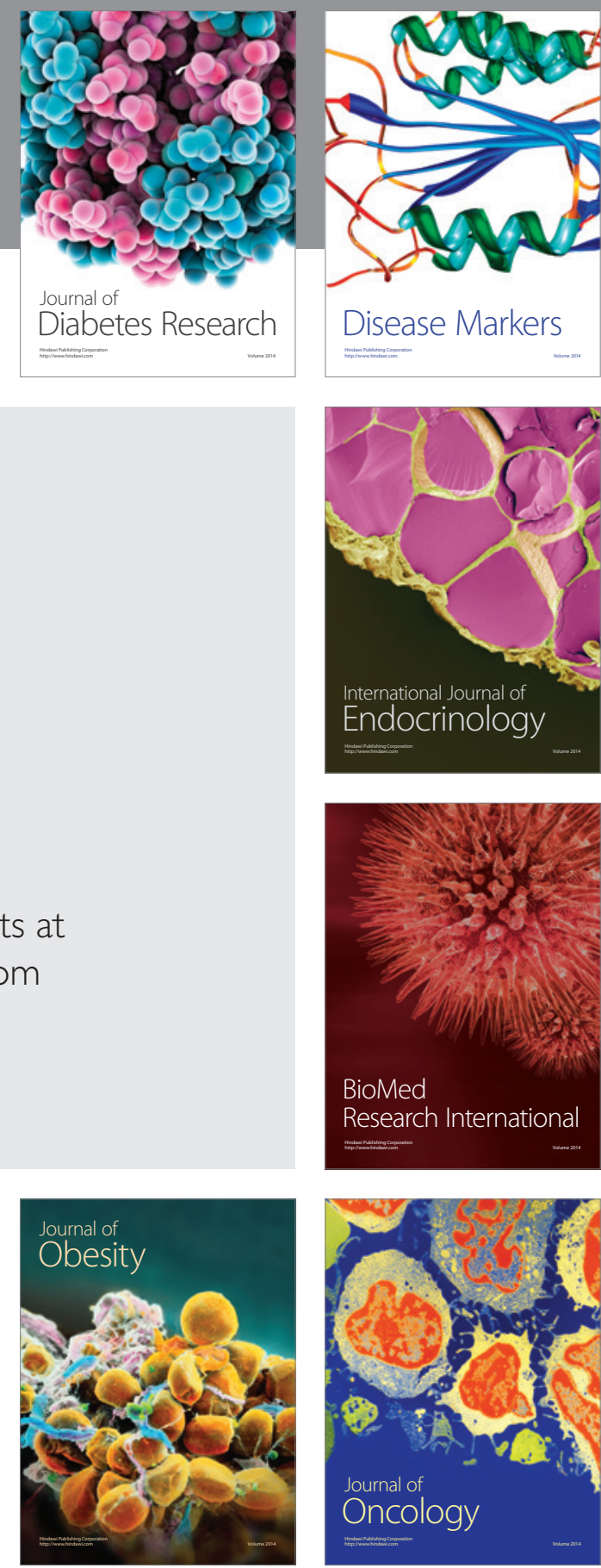

Disease Markers
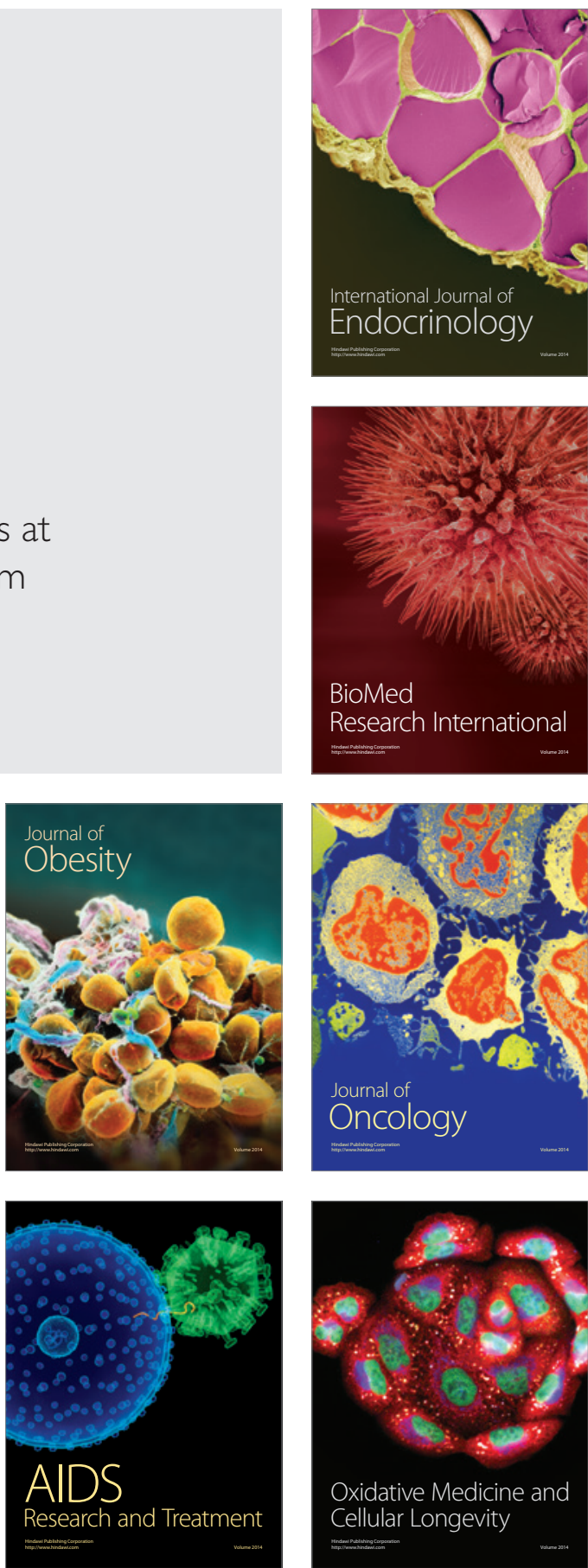